\title{
COMUNIDADE VISÍVEL: NARRADORES DE MEMÓRIAS E SUAS PRÁTICAS DE IMAGEM
}

\author{
Felipe Camilo Mesquita Kardozo ${ }^{1}$ \\ Glória Maria dos Santos Diógenes ${ }^{2}$
}

\section{Introdução à comunidade visível ${ }^{3}$}

Há uma comunidade que traz em sua história uma ou duas coisas que podemos aprender sobre imagem e memória. Há em sua geografia tão circunscrita e nas biografias tão imiscuídas algo que conduziria um visitante quase romântico a chamá-la de "comunidade" como quem houvesse acabado de ler o verbete em um dicionário. Litorânea, encontra-se em Fortaleza e a chamam de Poço da Draga.

Há ali, também, um conjunto heterogêneo de práticas de imagem ${ }^{4}$ diretamente relacionadas às narrativas de memórias e a uma política de defesa territorial entre os moradores do Poço. Com isso, quando aqui nos referimos àquela coletividade, a chamamos de modo mais estrito comunidade visível, acessível por meio de suas fotografias e de suas maneiras de narrar e lembrar com elas em mãos e em seu território. Não nos atrevemos, portanto, a tratar diretamente da memória ou da comunidade ali (categorias tão amplas e por vezes pouco "visíveis"). Nos dedicamos, porém, às práticas, imagens e narrativas observáveis entre os artifícios efetivos do empenho de seus moradores em lembrar e ser lembrado. Buscamos, assim, relatar quais experiências dessa comunidade podemos interligar, concentrando nossa atenção na visualidade de suas relações, em suas práticas e artefatos, sobretudo nas fotografias engajadas em "narrativas de memória" dos viventes dessa região.

\footnotetext{
${ }^{1}$ Universidade Federal do Ceará, Brasil. Email: felipecamilomk@gmail.com ORCID id: https://orcid.org/0000-0002-4833-1592

${ }^{2}$ Universidade Federal do Ceará, Brasil. Email: gloriadiogenes@gmail.com ORCID id: https://orcid.org/0000-0002-7494-8553 .

${ }^{3}$ Este texto é decorrente da tese Comunidade Visível: narradores de imagens e memórias do Poço da Draga desenvolvida por Kardozo (2021) sob orientação da Prof. ${ }^{a}$ Dr. ${ }^{a}$ Glória Maria dos Santos Diógenes. disponível em: https://www.repositorio.ufc.br/handle/riufc/58602 .

4 A fotografia, enquanto prática intimamente ligada aos trabalhos da memória, mobiliza e sedimenta espaços, tal qual as "práticas microbianas dos atores ordinários" nas grandes urbes, como Certeau (2009) define uma prática de espaço. O "espaço é um lugar praticado" (Certeau, 2009: 202). Nossos pequenos corpos erráticos se entendem com as vias da cidade enquanto se movem da mesma maneira que os olhos conduzem seu movimento visual por sobre manchas, pixels e texturas da fotografia em busca de sentido, afetando-se com o que encontram no caminho.
} 
Chamamos comunidade porque suas práticas de imagem estão associadas à partilha daquilo que é comum a muitos, também porque muitas das fotografias praticadas fazem parte desse "espólio comum", copiadas e compartilhadas de maneiras e em circunstâncias diversas. Chamamos comunidade também no sentido que se refere a uma malha de narradores, narrativas, imagens, ruas, celulares, álbuns, murais e filmes que nos permite, com o amparo de coisas visíveis, imaginar uma coletividade, seus lugares e suas histórias. Assim, quando nos referimos à comunidade visivel ${ }^{5}$, trata-se, por um lado, apenas daquilo que seus narradores e suas maneiras de praticar fotografias nos deixam ver, mas é também, por outro lado, toda essa multiplicidade que faz ver e se dá a ver.

$\mathrm{Na}$ medida em que nesses escritos ergue-se a relevante figura do narrador $^{6}$ e de sua presença tão singular nessa região litorânea, evidenciamos como o Poço da Draga se mostra um lócus privilegiado para pensar algo relacionado à categoria comunidade visivel. Chamamos alguns deles de memorialistas de esquina ${ }^{7}$, uma vez que esses narradores espontâneos se mostram tão cheios de fotos e lembranças para compartilhar nas calçadas de suas casas. Buscamos, aqui, relatar como se imprime, em relatos e acervos fotográficos, a particular autoidentificação de muitos desses memorialistas de esquina com o lugar onde nasceram e vivem até hoje - lugar marcado pela luta em defesa de suas moradias numa cobiçada ${ }^{8}$ região praiana da cidade. Alguns arquivam imagens de suas famílias quase que compulsivamente; outros fazem filmes "recheados" de fotografias; já outros brilham como resenhistas informais do time de futebol e do cotidiano da região. É sobre esses últimos que nos concentraremos neste artigo, visto que o caso impressiona, por urdir laços significativos entre alguns dos narradores emblemáticos do Poço e do time local, o Brasileirinho ${ }^{9}$. O grupo de entusiastas produz um ampliado acervo de lembranças do time, por meio da partilha, conservação e coleção

\footnotetext{
${ }^{5}$ A noção de comunidade surge aqui limitada a um universo da prática de imagens em um território, menos ancorada à literatura definidora do termo com Castells (1999) ou Bauman (2003) e mais relacionada à ideia de partilha do sensível (Rancière, 2009) - conjunto de evidências que revela a existência e a partilha do comum.

6 Pensamos com Benjamin (1994) a condição desse narrador do Poço da Draga que partilha suas experiências na calçada de sua casa.

${ }^{7} \mathrm{O}$ termo memorialistas de esquina alude à obra Sociedade de Esquina de Foote Whyte (2005).

${ }^{8}$ Passos (2019: 112) relata que, entre 1968 e 2013, ocorreram 04 momentos efetivos de retirada de famílias da região, por iniciativas de grupos econômicos ou da Prefeitura.

9 Apesar de ter começado a treinar no campo da Base Aérea de Fortaleza nos anos 70, segundo relata o jogador e dirigente Álvaro Graça, o Brasileirinho Futebol Clube comemora seu aniversário em 15/11/1982 — ano em que o Poço da Draga passa a sediar o time.
} 
de fotos e vídeos, promovendo ainda inúmeras resenhas ${ }^{10}$ via WhatsApp entre os exjogadores da equipe fundada em 1982 e que hoje já não compete mais.

Em se tratando de uma região com história centenária de maioria negra ${ }^{11}$, em uma metrópole brasileira marcada pela herança colonial e pelo individualismo neoliberal, enxergamos resiliência no Poço da Draga quando pensamos em seus laços de solidariedade e parentesco, bem como nas narrativas e imagens que surgem, refluem, insistem em ser lembradas nesse pedacinho de Fortaleza. É disso que esses escritos tratam ao relatar a trajetória do Brasileirinho como uma fração metonímica dos laços e prática de narradores de memórias do Poço. Deste modo, conhecer a história do time de futebol de subúrbio ${ }^{12}$, tão caracterizada por dinâmicas de composição e partilha de fotografias, nos ensina também sobre uma constelação mais ampla de memórias em que ele está inserido, a comunidade visivel.

\section{O Poço}

Diferente de qualquer extensa favela carioca que, porventura, povoe a nossa imaginação, o Poço da Draga não está, a rigor, em uma região dita de periferia com baixo $\mathrm{IDH}^{13}$, mas sim entre o centro comercial e a orla turística da cidade, circundado por equipamentos culturais (Figura 1). A precariedade da estrutura física da área se contrasta com os prédios avizinhados, que dão suporte às atividades artística e comercial da cidade. O ruído do mar, o baixo movimento de veículos e as velhinhas de cadeiras na calçada aludem a uma passagem do tempo também discrepante dos fluxos velozes do capital. Talvez seja por isso que projetos do Governo do Estado do Ceará de readequação da orla para fins turísticos, como a obra do Acquário de Fortaleza ${ }^{14}$, sempre encontrem

${ }^{10}$ A resenha é uma prática narrativa lúdica conduzida pelo coletivo dos jogadores de um time em decorrência de suas lembranças de jogos vivenciados. . Alvinho, morador do Poço, costumava ser o anfitrião da resenha após os jogos. Hoje as resenhas acontecem à distância, via internet.

${ }^{11}$ O geógrafo, morador e integrante do movimento Pró-Poço Sérgio Rocha (2016) apresenta dados sobre a identidade étnica e territorial da região num levantamento protagonizado pela própria comunidade. Os dados revelaram uma população de 1.200 moradores. Desses, $94 \%$ desejam permanecer morando lá; $88 \%$ afirmam que, sem o acesso direto à praia, o Poço perderia a identidade. Além disso, o estudo afirma que "a grande maioria da população residente no Poço da Draga se considera parda ou negra" - 59 e 16\%, respectivamente.

${ }^{12}$ Futebol de subúrbio é um termo corrente entre jogadores para a prática esportiva não profissional autoorganizada que acontece em campos e quadras dos bairros da cidade.

${ }^{13}$ Índice de Desenvolvimento Humano (IDH), utilizado pela ONU para nortear políticas públicas.

14 "O aquário, idealizado em 2008 pelo então governador Cid Gomes (PDT) para incrementar o turismo e atrair 1 milhão de visitantes por ano, ainda não saiu do papel. Com a construção iniciada em 2012 (...) os trabalhos se interromperam definitivamente em 2015". Disponível em: https://www.gazetadopovo.com.br/haus/estilo-cultura/acquario-ceara-obra-de-aquario-encalha-empraia-famosa-de-fortaleza/ . Acesso em: 5 nov. 2019. 
resistência na única população de descendentes de pescadores que ainda se mantém em seu território litorâneo, incólume às remoções promovidas na região ao longo dos anos.

Circundada pelos espaços públicos do Centro Dragão do Mar de Arte e Cultura e da Caixa Cultural ${ }^{15}$, é preciso saber olhar para perceber o quão grande e visível é a comunidade. Ao mesmo tempo à beira-mar e à margem do calçadão turístico da orla, o local não possui saneamento básico, escola pública ou posto de saúde. Moradores informaram que, apesar de se situarem na Praia de Iracema, em suas contas de iluminação está indicado como bairro "Centro". Relatam, ainda, sua apreensão de que, em caso de uma eventual remoção, sejam indenizados com parâmetros imobiliários de menor valor. Tal especulação tem um pouco menos a nos dizer sobre os atuais planos estatais para a região e mais nos fala sobre o estado de alerta dos moradores e sobre sua forte identificação com a localidade onde vivem ${ }^{16}$.

Figura 1 - Mapa do Poço da Draga (Fortaleza, Ceará, Brasil) no qual indicamos em amarelo algumas de suas entradas e em vermelho nosso perímetro de atuação

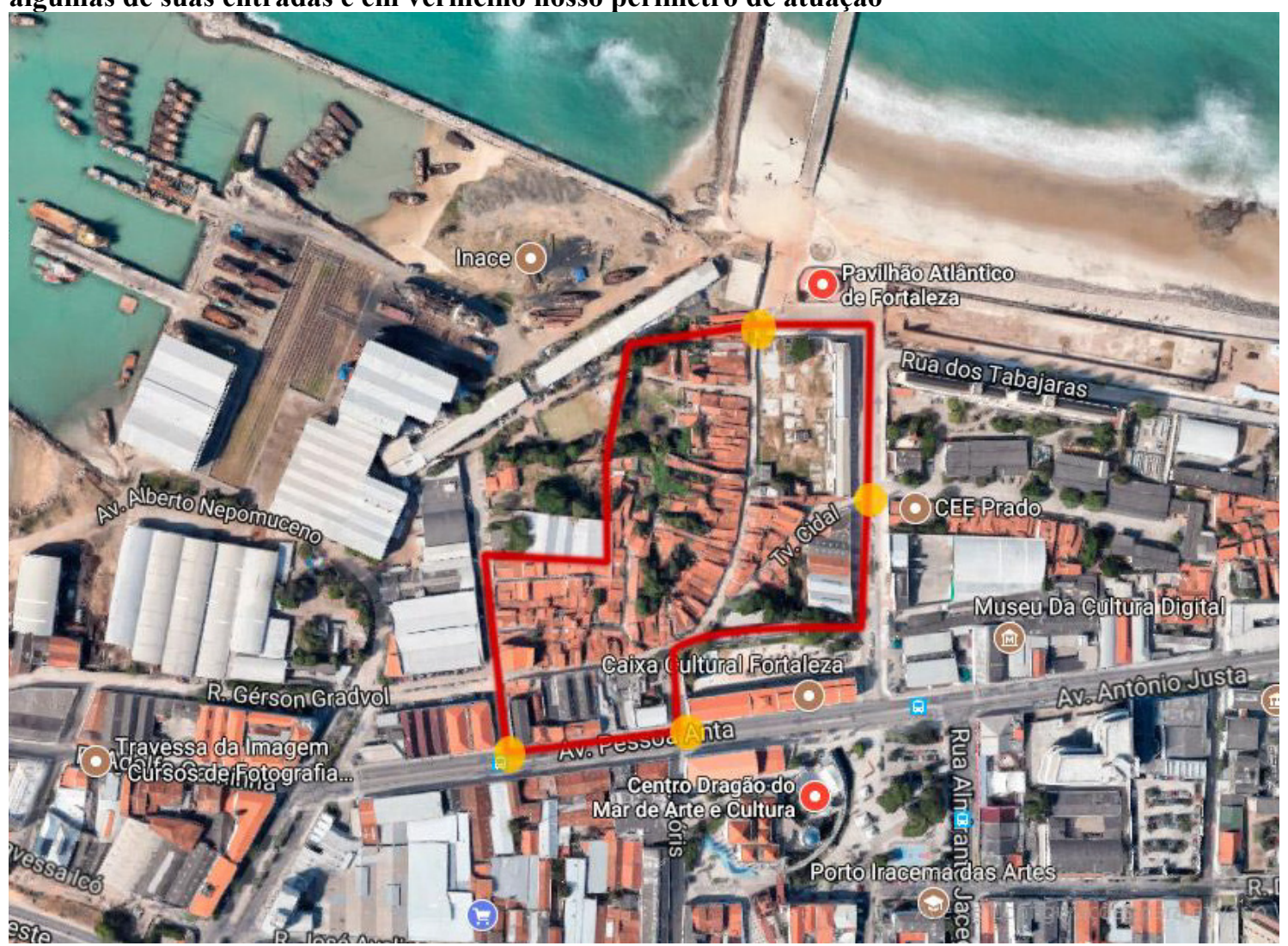

Fonte: https://www.google.com.br/maps.

${ }^{15}$ O Centro Dragão do Mar de Arte e Cultura é um equipamento localizado em Fortaleza, mantido pelo Governo do Estado do Ceará. A Caixa Cultural, outro equipamento dessa ordem, mantido pelo Banco Caixa Econômica, encontra-se no prédio da antiga Alfândega, esquina com o Poço da Draga.

${ }^{16}$ Sobre o histórico de luta pelo território e a identificação da comunidade com o seu lugar, recomendamos a leitura de Neivania Silva Rodrigues (2018) e Marília Passos (2019). 
A região que daria lugar ao Poço da Draga começou a ganhar forma já em 1906, em frente à antiga Praia do Peixe (hoje Praia de Iracema). Com a construção de um porto (que hoje tem as ruínas conhecidas como a Ponte Velha), um povoado começou a se estabelecer. No entanto, em 1950, com a criação do Porto do Mucuripe a poucos quilômetros dali, a região perdeu grande parte de seu propósito comercial, ganhando o caráter mais residencial que vemos hoje. Segundo dado de pesquisa colaborativa conduzida pelo geógrafo Sérgio Rocha (2016), morador da região, cinco anos atrás o Poço reunia cerca de 1.200 pessoas. Dia 26 de maio de 2021 comemora-se os seus 115 anos de existência ${ }^{17}$. Na Praia de Iracema, pobreza e riqueza se avizinham. É visível o contraste entre o mármore de hotéis e repartições tão imediatamente próximos à vizinhança de pequenas casinhas e ruas sem asfalto. Isso se agrava se ao temor da remoção somamos as efetivas violências policiais ${ }^{18}$, em um delicado contexto de "crise na segurança no estado"19 e de confronto com o crime organizado. Tais dificuldades sociais e infraestruturais não minimizaram, no entanto, o apego ao território nas falas de descendentes dos primeiros moradores do local.

Essa identificação e a luta comunitária contra remoções ao longo dos anos fez com que movimentos de moradores adotassem, em sua estratégia política, esforços de visibilizar o Poço da Draga como polo de memória da cidade. Como nos lembra Linda Gondim (2001: 186), “o espaço físico tem papel crucial na constituição da memória coletiva. A relativa estabilidade de tal espaço permite-lhe atuar como âncora da memória". Associamos a condição histórica, a tradição geracional e essa abordagem política sobre a memória da comunidade à peculiar presença de moradores com acervos e narrativas eloquentes que atravessam mais de três gerações.

Em nossos diálogos com os moradores, muitas das fotografias que brotavam em seus celulares se referiram a localidades modificadas com o passar dos anos, que foram

\footnotetext{
${ }^{17}$ PASSOS (2019) discute sobre o ato político dos moradores do Poço da Draga ao celebrarem o aniversário da comunidade no dia de Inauguração da Ponte Metálica, em 26 de maio de 1906.

${ }^{18}$ São recorrentes notícias como: "Atleta de triatlo denuncia ter sido agredido por PMs quando saía para treinar com filho na Praia de Iracema". Disponível em: https:/g1.globo.com/ce/ceara/noticia/ 2018/11/29/atleta-de-triatlo-denuncia-ter-sido-agredido-por-pms-quando-saia-para-treinar-com-filhona-praia-de-iracema.ghtml. Acesso em 5 nov. 2019.

${ }^{19}$ Nos referimos à série de 169 ataques criminosos em 42 cidade cearenses em janeiro de 2019. "O contexto da violência no estado é marcado atualmente pelo fortalecimento de grupos que migraram do Rio de Janeiro e de São Paulo para o Ceará, como o Comando Vermelho (CV) e o Primeiro Comando da Capital (PCC), além da Família do Norte, surgida no Amazonas, e de facções locais."

Disponível em: https://www.brasildefato.com.br/2019/01/09/ceara-seguranca-publica-e-tratada-comamadorismo-e-bravatas-afirma-pesquisador/. Acesso em: 5 nov. 2019.
} 
registradas indiretamente no fundo de retratos posados de familiares em momentos de lazer. Quando percebia a ausência de imagens que testemunhassem sua afetação com as mudanças, o narrador interrompia o corriqueiro memorialismo de esquina para buscar fotos nas suas redes de contatos no WhatsApp ou o testemunho direto do vizinho mais próximo. Tal iniciativa chegava ao nível do afinco empreendido por seus moradores em fotografar com o celular as imagens de seus álbuns e murais de casa para compartilhar. Observa-se, nessa transmudação da imagem, sua passagem de estatuto do universo exclusivamente autobiográfico, de um acervo particular, para a formação de uma "teia de emaranhados vitais" (Ingold, 2012), formada por fios de memória da coletividade.

Percebemos, nas tantas idas e vindas ao Poço, que o tempo atua ali como lente que recria e transforma, atualizando as relações das pessoas com suas imagens, como se elas projetassem outras modulações dentro do mesmo espectro figurativo ou digital. Por exemplo, os rostos retratados numa festa infantil podem, na contemplação de rastros da memória, se tornar fundo, imagens borradas ou desfocadas, para dar destaque às construções de vestígios da memória - como no caso de rótulos antigos de garrafas de refrigerante ou de estampas de uma anacrônica toalha de mesa desbotada. A fotografia, capaz de ideações (Samain, 2012), age em nossas relações da mesma forma que o desdobramento das relações entre pessoas em seus territórios modifica suas práticas com as imagens. No Poço, cada imagem biografa o espaço e é mais do que se vê; é concretude e ausência; é aquilo que vemos e o (tanto do) que nos olha (Didi-Huberman, 1998).

Como podemos ver na Figura 2, a infância da geração de Álvaro Graça Júnior (um de nossos interlocutores sobre o qual falaremos mais adiante) foi documentada nas imagens que contam a história do Brasileirinho. Na fotografia que vimos no grupo de WhatsApp do time, Álvaro e outras crianças em novembro de 1994 comemoram o aniversário de 12 anos da equipe na comunidade. Com bolo, velinhas, refrigerante, em nada se distingue de outras fotos de festinhas infantis da época, não fossem os dizeres impressos em papel branco e colados na parede de cimento ao fundo: "Feliz Aniversário Brasileirinho / BRASILEIRINHO FUTEBOL CLUBE / O B.F.C. Convida todos / Seu aniversário 15.11.94”. Um homem de pandeiro na mão indica que havia música. E as manchas de desgaste e as bordas da imagem indicam que a foto do acervo impresso de um membro do time foi digitalizada de maneira informal com o celular para compartilhála na rede. Estamos diante da imagem de uma imagem que carrega rastros de seu envelhecido suporte de papel, da prática que a digitalizou e das muitas biografias 
preservadas ao mesmo tempo em que os jogadores do Brasileirinho registravam a história do time do Poço.

\section{Figura 2 - Festa de Aniversário do Brasileirinho F.C. (1994)}

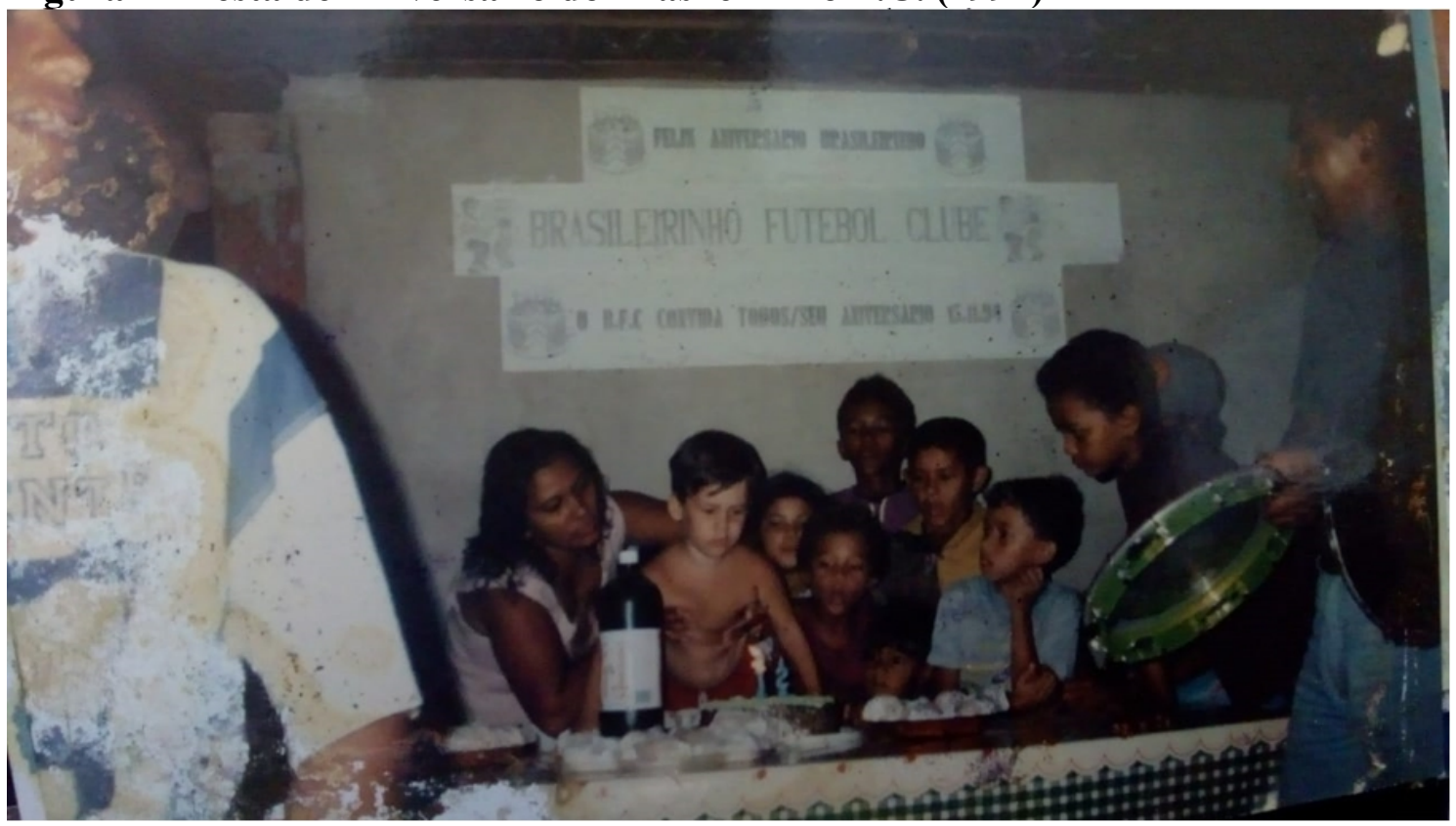

Fonte: Acervo pessoal de Álvaro Graça Jr.

Tratamos assim de ver os narradores do Poço se servirem de fotografias e ouvilos narrar o que viam e como elas os afetaram e os afetam - algo próximo à abordagem fotobiográfica ${ }^{20}$ de Fabiana Bruno (2012), porém mais atento às imagens digitais manuseadas em celulares nas calçadas. Trata-se também de fazer filosofia com gente dentro, maneira da antropologia de abordar o mundo, como observa Viveiros de Castro (2002) em diálogo com Tim Ingold (1992) ${ }^{21}$. Fazer uma antropologia compartilhada, pensar em diálogo com memorialistas de esquina, observar suas práticas e concepções coloca em xeque nossos entendimentos unilaterais sobre como nos relacionamos com fotografias, inclusive com as nossas. Dessa fricção filosófica brotou a questão que nos move a escrita: como um narrador mobiliza seu dispositivo celular, seu acervo pessoal e suas redes digitais na configuração de uma constelação ${ }^{22}$ de imagens que lhe servirão de

\footnotetext{
${ }^{20}$ Fabiana Bruno (2010) apresenta à prática antropológica a noção de fotobiografia, como forma de produzir saber sobre a história de alguém, de um lugar, tendo como instrumentos fotos e narrativas.

${ }^{21}$ Viveiros de Castro se refere à "possibilidade de uma atividade filosófica que mantenha uma relação com a não-filosofia — a vida — de outros povos do planeta" (Viveiros de Castro, 2002: 127).

${ }^{22}$ Vemos em nossos narradores a prática de pensar com constelações de imagens, procedimento presente nas considerações de Warburg (2010) sobre o atlas. Didi-Huberman (2018) diz que um atlas é ao mesmo tempo uma forma visual do saber e uma forma sábia do ver.
} 
evidências, testemunhas, actantes ${ }^{23}$, ferramentas de suas memórias na execução de narrativas sobre $\mathrm{si}^{24}$, sobre seus espaços e sobre sua comunidade?

\section{Narradores, moradores, jogadores}

Não falamos de um narrador "genérico", como se fosse possível a qualquer um lembrar e relatar qualquer coisa em qualquer lugar. Aqueles que nos contam suas histórias no Poço têm a pele escura e convivem com a precariedade infraestrutural na rua de suas casas. Cremos que, também por tais adversidades, esses narradores se caracterizam com seus vastos acervos de imagem em mãos. Se consideramos que são esses os corpos que a necropolítica ${ }^{25}$ (Mbembe, 2018) escolhe expor à morte no Brasil, percebemos redobrados os esforços dos memorialistas de esquina contra a morte e o apagamento, há anos e "anos contrariando a estatística”, como diriam os Racionais $\mathrm{Mc}{ }^{26}$.

Humilhado e profundamente desonrado, o negro é, na ordem da modernidade, o único de todos os humanos cuja carne foi transformada em coisa e o espírito em mercadoria - a cripta viva do capital. Porém — e esta é sua patente dualidade —, numa reviravolta espetacular, tornou-se o símbolo de um desejo consciente de vida, força pujante, flutuante e plástica, plenamente engajada no ato de criação. (Mbembe, 2014: 19).

É esse desejo consciente de vida do qual nos fala Mbembe que vemos nas narrativas de ex-jogadores do Brasileirinho, time ativo por quase quarenta anos nos jogos de futebol de subúrbio de Fortaleza. Pausou suas atividades recentemente, devido ao contexto dos conflitos entre facções criminosas. Como relatam dirigentes da equipe, a mobilidade dos jogadores entre bairros tornou-se arriscada. Isso, porém, não os impediu de fortalecerem seus laços e lembranças, mesmo não se tratando de uma organização com recursos destinados à conservação de um acervo ou arquivo. Assim, compartilhando fotos e resenhando jogos antigos, algumas dezenas de jogadores trabalham coletivamente suas memórias por meio do grupo "Resenha do Brasileirinho" no WhatsApp. Como alude

\footnotetext{
${ }^{23}$ Consideramos, com Latour (1994), a simetria de agência entre humanos e não humanos.

${ }^{24}$ Em sua dissertação, Kardozo (2013), aponta nas redes digitais uma incitação a práticas confessionais como traço nas subjetividades de usuários de redes como Facebook e Instagram. O trabalho observa tais interações digitais atento à noção de subjetividades alterdirigidas de Sibília (2007), assim como à marca da confissão em nossa cultura (Foucault,2009) e ao conceito de dispositivo também foucaultiano (2000), retomado por Agamben (2005).

${ }^{25}$ Assim Mbembe nos apresenta seu livro Necropolítica: "Na economia do biopoder, a função do racismo é regular a distribuição da morte e tornar possíveis as funções assassinas do Estado. Segundo Foucault, essa é "a condição para aceitabilidade do fazer morrer" (2018: 18).

26 “Capítulo 4, versículo 3” é uma canção de Racionais MC’s de 1997.
} 
Ecléa Bosi (1994), lembrar não é reviver; é reconstruir experiências com imagens e pensamentos - a memória é trabalho, e não somente sonho. Dessa forma, os laços de comunidade litorânea e a identificação com o esporte favoreceram a frequência desses narradores na rede digital. Assim como o Poço da Draga, a chegada do futebol no continente e no Ceará tem uma relação íntima com o mar. Relata Eduardo Galeano (2019: 38) que "linda viagem, a que havia feito o futebol: tinha sido organizado nos colégios e universidades inglesas, e na América do Sul alegrava a vida de gente que nunca tinha pisado numa escola”. Nirez de Azevedo (2002: 15) conta que em 1903 ancorou em Fortaleza um navio inglês com futebolistas da Europa que iam para o sul do País e para a Argentina, "onde o futebol já estava bastante avançado". Em dezembro do ano seguinte, 1904, ocorreu o primeiro jogo entre um time de funcionários de companhias britânicas e um time de cearenses ricos e brancos. Como já relatamos, por essa época, em 1906, foi inaugurada a Ponte Metálica — a Ponte Velha, como chamam os moradores do Poço. Dessa relação entre o vigente imperialismo europeu e uma Fortaleza que se europeizava nos costumes ${ }^{27}$, aportam em nossa praia duas coisas com as quais tanto se identificam nossos narradores: o território constituído ao redor da ponte e o lazer com bola nos pés.

Eram os pobres que o enriqueciam, enquanto o expropriavam. Este esporte estrangeiro se fazia brasileiro, na medida em que deixava de ser o privilégio de uns poucos jovens acomodados, que o jogavam copiando, e era fecundado pela energia criadora do povo que o descobria. E assim nascia o futebol mais bonito do mundo, feito de jogo de cintura, ondulações de corpo e voos de pernas que vinham da capoeira, dança guerreira dos escravos negros, e dos bailes alegres dos arredores das grandes cidades. (Galeano, 2019: 38)

27 Pontes (2014) descreve o período entre 1860-1930 como Fortaleza Belle Époque, quando a cidade se modificava sob referência cultural europeia, sobretudo francesa. 
Figura 3 - Ceará, Campeão Cearense de 1915 (acervo do clube)

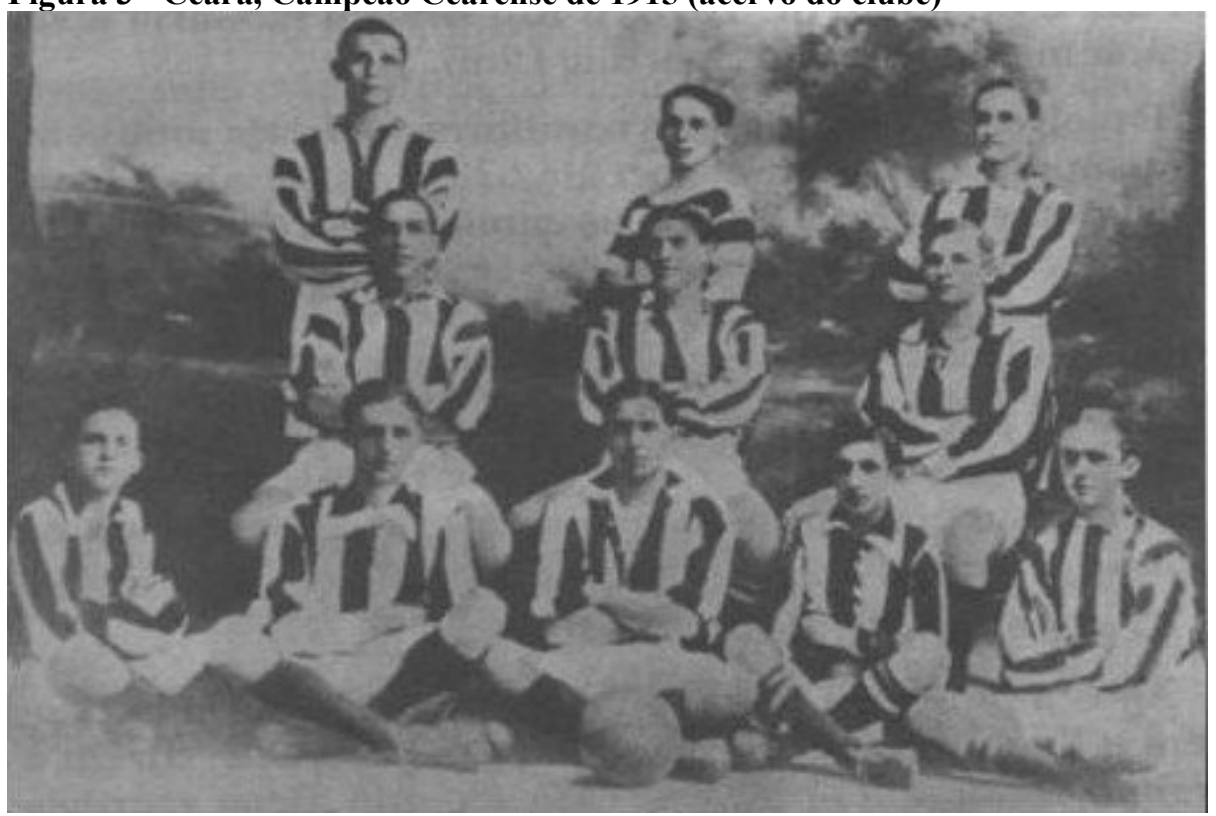

Fonte: Assessoria de imprensa do Ceará Sporting Club.

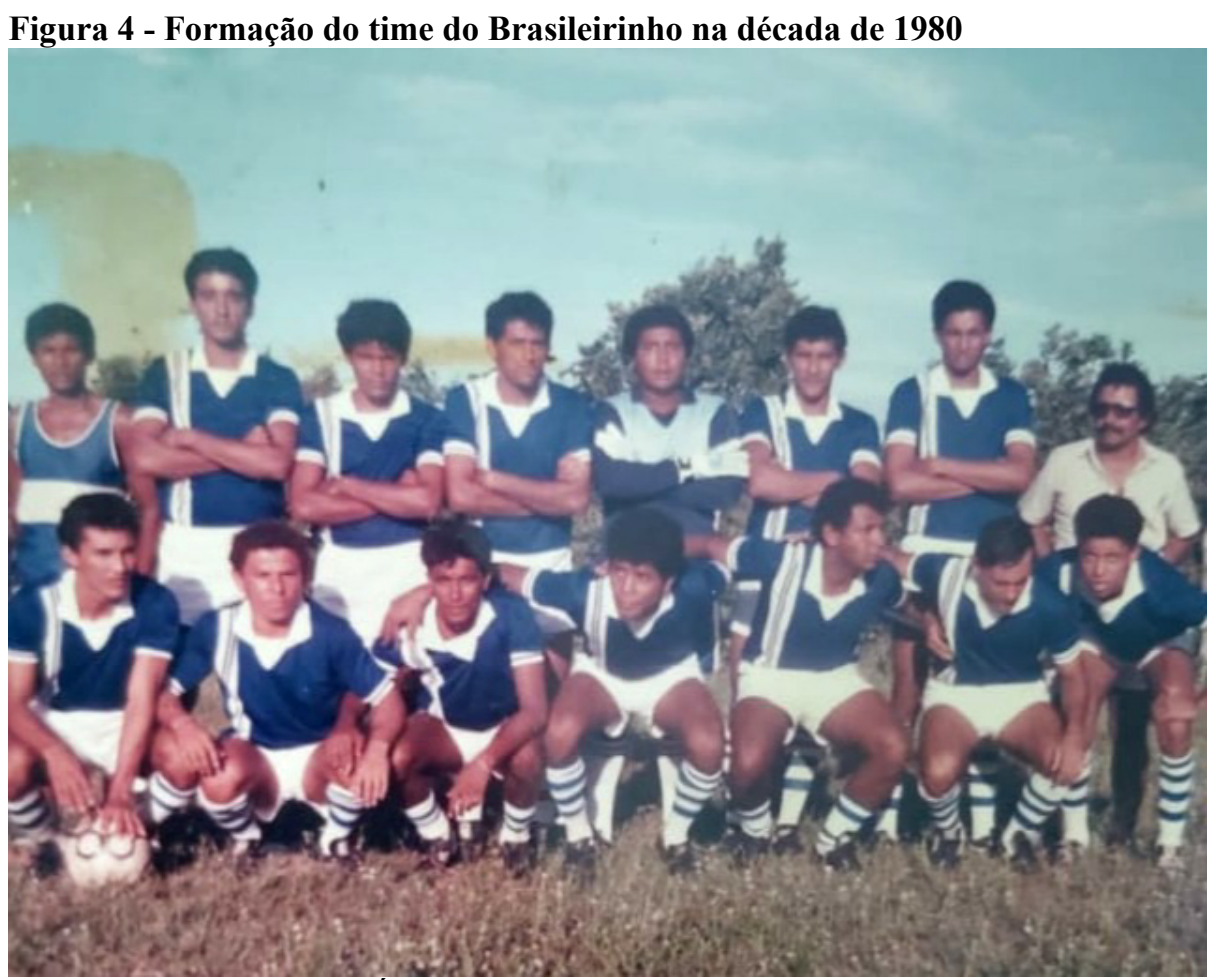

Fonte: Acervo pessoal de Álvaro Graça, dirigente do time.

Décadas após a abolição da escravidão no Ceará (1884), ainda não havia um jogador negro na formação dos clubes cearenses. Segundo relato de Sidney Barbosa da 
Silva no site da Federação Cearense de Futebol ${ }^{28}$, em 1915 foi organizado o primeiro campeonato cearense pela Liga Metropolitana, a qual seria "excludente, pois dela participaram apenas equipes da elite de Fortaleza [...] os clubes excluídos (dos pobres, trabalhadores e negros) acabaram por formar seu próprio campeonato e liga". Isso só mudaria a partir dos anos 1920, com a profissionalização do esporte local, que passou a receber jogadores de outros estados do País e de diversas origens étnicas e econômicas.

Vejamos como contrastam tais questões nas Figuras 03 e 04, sendo a primeira uma foto da formação do time do Ceará de 1915 e a segunda foto uma formação do time do Brasileirinho dos moradores do Poço dos anos 1980. Como observa Didi-Huberman (1998), as imagens têm mais memória e porvir do que nós que as olhamos. Ao observar formalíssimas fotografias do "quadro" de dois times, nas quais 22 homens posam frontalmente uniformizados, aludimos ao semelhante "amor pelo futebol", que ainda não rendia fortuna ao jogador, mas ao mesmo tempo às distintas condições sociais de suas práticas esportivas. Se na foto em preto e branco, nos uniformes e nas poses podemos intuir um esporte se formalizando, contamos apenas com o relato histórico para lhe problematizar racialmente.

Já décadas à frente, a fotografia do Brasileirinho, povoada por corpos de pele escura, carrega também outros indícios disso que seus jogadores chamam futebol de subúrbio. Vemos aqui, como Samain (2012), "um grande jardim de arquivos vivos" a imagem como uma "supervivência". Ainda que posem para a foto, nem todos os jogadores olham para frente, nem todos têm os braços cruzados em pose imponente, como os outros na foto anterior, o que nos permite imaginar que ali não se relacionam necessariamente disciplina e vontade de jogar. Não se trata do corpo unido de uma equipe profissional, mas de uma distinta multiplicidade cujos corpos e olhos apontam para onde querem. Álvaro Graça, Alvinho ${ }^{29}$, pai do já mencionado Álvaro G. Jr., jogador, dirigente do time e velho morador do Poço conta que

\begin{abstract}
Anos 90 o time era todo assentadinho. Ainda saiu jogador profissional daqui cara. Nós tínhamos jogadores profissionais aqui também. Naquele tempo os meninos nem ligavam de jogar em time de Fortaleza, Ceará. Porque não dava dinheiro. Eles, empregados, ganhavam mais dinheiro e num ficavam presos. Queriam beber a cachaça deles, queriam beber, queriam brincar, queriam tudo... Agora [...] qualquer jogador ganha dinheiro. (informação verbal) ${ }^{30}$
\end{abstract}

\footnotetext{
${ }^{28}$ Disponível em: www.campeoesdofutebol.com.br/ceara_historia.html. Acesso em: 25 ago. 2020.

${ }^{29}$ Álvaro Graça, Alvinho, é morador do Poço desde que nasceu. Herdou do pai o amor pelo futebol e também a profissão de portuário. Também é pescador. "Seu Graça", seu avô, cuidava para a família Boris do terreno por sobre o qual o Poço da Draga se expandiu.

${ }^{30}$ Alvinho, entrevistado em 17/07/2020.
} 
Figura 5 - Registro de Cláudio "He-man" comentando fotos antigas em seu celular, 2017

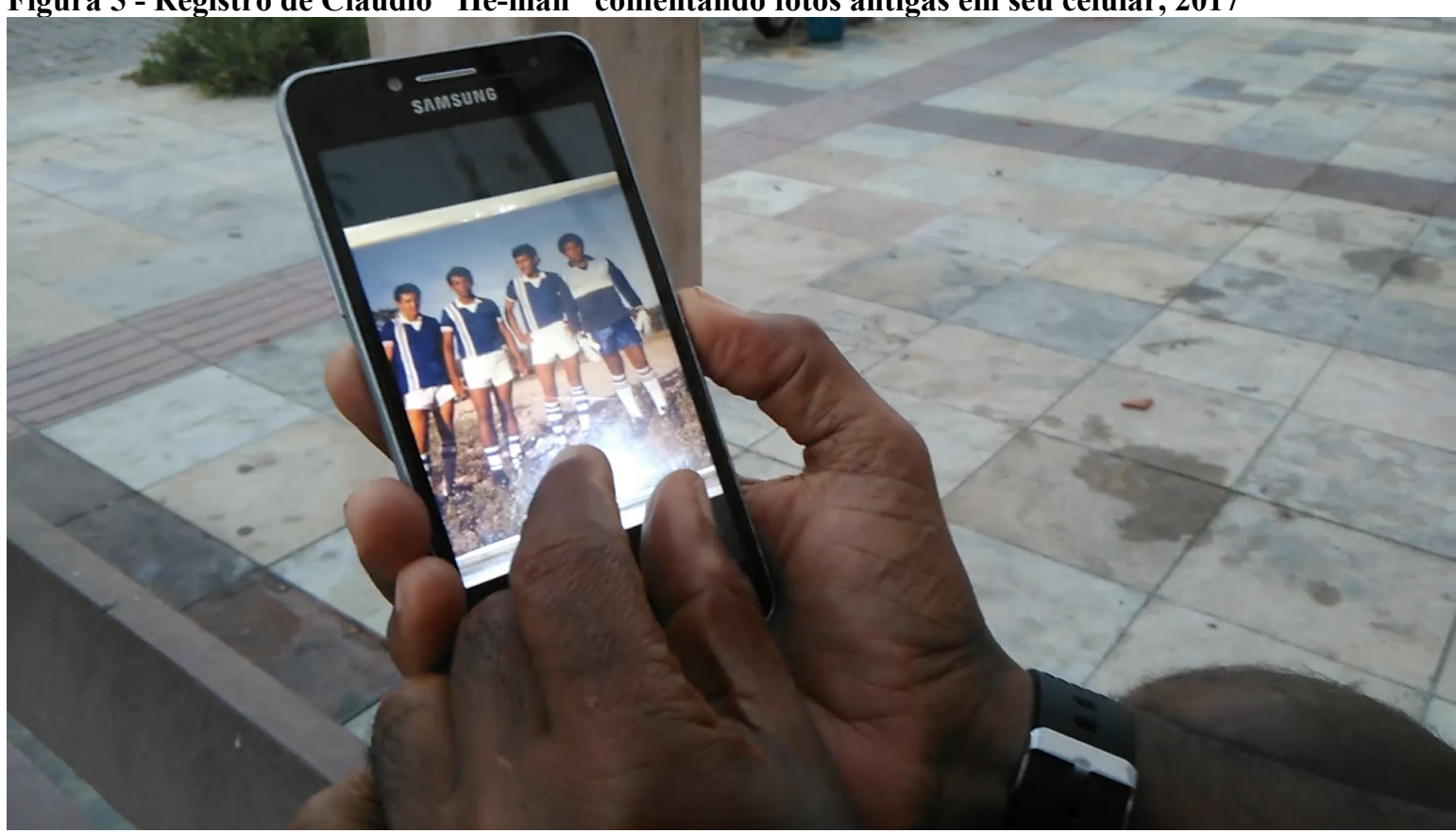

Fonte: Vídeo, acervo da pesquisa.

Em um outro momento, seguimos Teco ${ }^{31}$, Álvaro Graça Jr., fillho de Alvinho, que nos apresenta Cláudio He-man na av. Almirante Tamandaré. O grande homem negro, na casa dos 50 anos, hoje trabalhador do cais do Mucuripe, é ex-jogador do Brasileirinho. Nesse dia ele não estava acompanhado e ouvia em seu celular "Tu és o MDC da minha vida", canção de Raul Seixas. Filmamos seus apontamentos sobre fotografias de seu celular. Cláudio narrava a história do time quando Teco se afetou com uma foto em que aparece seu pai. Mais uma vez, o acervo fotográfico, previamente em um celular, ativa os trabalhos da memória. Apesar de falar com frequência das quatro gerações que o ligam ao Poço, Teco se envolveu na conversa após ver sua biografia atravessada não apenas pela história do amigo, mas do próprio território (Fig. 5).

[...]. Eu, Repeteco, Cleiton, Álvaro, Baianinho e Marcos Davi [...]. Aí tem essa daqui que já tá muito antiga. [Álvaro pergunta 'tu foi lá em casa bater essas fotos, foi?'] Não, essa eu mesmo tinha. Era meu álbum. Eu acho que eu tenho esse álbum em casa...é porque foram tirando as fotos naquela época. (informação verbal) ${ }^{32}$

É interessante observar como muitos dos membros do time tinham seus álbuns com cópias das mesmas fotos e, por vezes, os que não tinham pediam aos colegas que

\footnotetext{
31 Teco, Álvaro Graça Jr., é filho de Alvinho e colaborador muito significativo para a pesquisa. Tem 39 anos e é da quarta geração de sua família no Poço. É documentarista e entusiasta do Brasileirinho.

${ }^{32}$ Cláudio He-man, em entrevista informal no Poço da Draga em 18/07/2018.
} 
lhes fizessem uma cópia digital. Seus diálogos, exercícios de rememorar a dois, são tão fácil e visivelmente ativados pelas fotografias que, como observa Barthes (2015), atestam juntos realidade e passado (dizem isso foi) como nenhuma outra linguagem. Vale pensar que esse conjunto de imagens, organizado continuamente, recomposto de acordo com a inserção de novas figurações, de novas imagens “conseguidas" por algum morador, forma uma espécie de mapa, de Atlas Menemosyne (Didi-Huberman, 2013: 15), operando como máquina de leitura, forma de ler o mundo, de ligar as coisas do mundo.

O conjunto de imagens permite ver, atualizar uma espécie de "enciclopédia de movimentos em constantes andanças no tempo" (Samain, 2012: 56). A formação dos álbuns, a partilha e a organização coletiva das imagens no Poço - essa eu mesmo tinha, aí tem essa daqui que é muito antiga — possibilita que a comunidade invisível produza, assim, a trama da memória de gestos de um time, de seus jogadores, de seus campeonatos, em movimentos contínuos de atualização. Ao invés de se colocar como um esforço de recriação do passado, o fazer e refazer os álbuns, bem como as partilhas de imagens digitais no WhatsApp, possibilitam que imaginação e memória operem novas relações entre os "brasileirinhos", sempre conduzida por "princípios móveis e provisórios" (DidiHuberman, 2013: 14). No diálogo com Benjamin, Didi_Huberman (2013: 16) lembra que as máquinas, ou "caixas de leitura", possibilitam que se leia o que nunca foi escrito, "a leitura antes de toda a linguagem". O Brasileirinho deixa de entrar em campo, mas faz permanecer o jogo entre imagens, das imagens.

\section{Figura 6 - Foto do Quadro do Brasileirinho F. C. nos anos 1980}

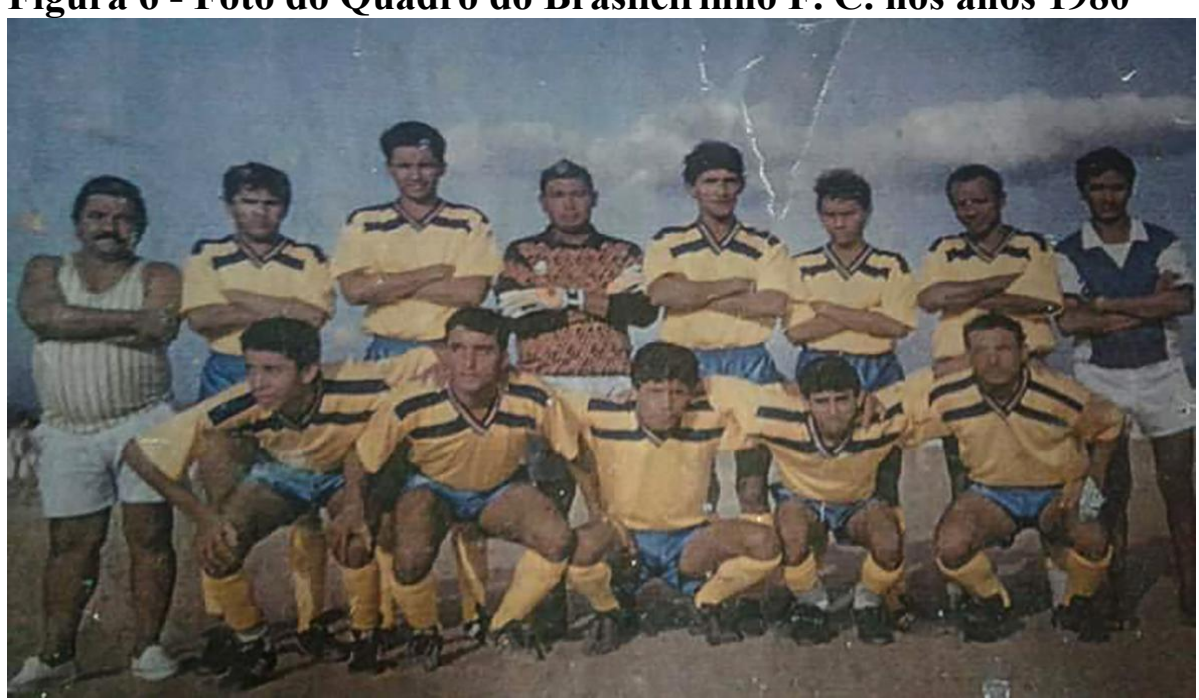

Fonte: Grupo de WhatsAppResenha do Brasileirinho. 
Assim, o aparelho tão propício à produção de mensagens e imagens rapidamente consumidas e esquecidas se torna um dispositivo profanado (Agamben, 2005) pela força de um desejo de lembrar coletivamente movido pelos resenhistas do Brasileirinho. A máquina veloz de compartilhar informação é modulada por outra temporalidade que é a do jogo de repetir, do recriar, reencenar velhas histórias. Nossos narradores do Poço talvez viguem Benjamin (1994) que lamentava que a predominância da informação nas culturas relegaria ou decretaria a extinção da prática épica de narrar experiências. Contar histórias em grupo é tática na luta contra o esquecimento por parte daqueles que não contam com a formalidade de uma instituição dedicada à conservação de suas memórias. Não contar com isso favorece esse (e)terno retorno aos trabalhos da memória, aos jogos da resenha.

A imagem de capa do grupo Resenha do Brasileirinho pode ser vista na figura 6. Trazemos ela aqui por se tratar de uma dessas fotos que é reincidentemente lançada na conversa por um membro do grupo pedindo para alguém puxar a resenha. É diante dessa foto desbotada pelo tempo e pixelizada, por se tratar de uma digitalização de baixa definição, que Alvinho nos conta da escalação do time.

Goleiro era o Silvio e o Einha que era o reserva dele. Aí como eu lhe disse o treinador, né, ele queria o Silvio, não queria o reserva. Aí o lateral direita Mendes. Aí a zaga Toinho Popó (Luiz Paulo, filho do Luizão Zagueiro). Aí Lateral Esquerda era Cláudio He-Man. Volante Bibinha. Meio de Campo Joãozinho e Mazinho. Ponta direita Carlinho Bibi o bichão lá da resenha. Centro Avante é o magnífico, é o homem gol de todos os tempos, Santão Goleador. Ponta esquerda se chama Lupercine (Luciano). Era o jogador que todos os anos ele era o artilheiro do sertão. Treinador aí, Herói do Sertão Chico Barrigudo. Esse aí era o herói do Sertão, o time e ele, porque ele passou cinco anos sem perder uma partida. Ele treinou o time muitos anos, macho. Ele tinha o time na mão, que é como eu tô lhe dizendo. O time quando era elite, ele teve dois treinadores que eram o Chico Barrigudo e o Chicão.(informação verbal) ${ }^{33}$.

Não está em nossa alçada perscrutar a carga afetiva e as recordações destinada por Alvinho ao falar cada nome diante das manchas pouco nítidas em que o presidente do time decifra o rosto de cada um de seus colegas. Talvez nos baste mencionar a intensidade que caracteriza tal prática de imagem, desse tempo mágico (Flusser, 2012) no qual os olhos cansados de pescador circulam entre as faces enfileiradas dos camaradas, cada qual ancorada a certas histórias. Em meio às posições futebolísticas descritas, apelidos no diminutivo dão o tom fraternal e bem-humorado com o qual o velho jogador guarda os amigos na memória. Já a predominância de amarelos e azuis nos uniformes não

\footnotetext{
${ }^{33}$ Álvaro Graça Júnior “Teco”, transcrição de mensagem de áudio enviada por WhatsApp em 27/07/2020.
} 
nos deixam esquecer o ar patriótico no nome do Brasileirinho - homenagem à seleção de futebol do país. A solenidade do uniforme poderia ser reforçada pela pose séria de braços cruzados dos jogadores de pé, não fosse o caso de alguns estarem sorrindo, um dos agachados sequer estar olhando para a câmera, entre estes mais abaixo intimidade e equilíbrio são encontrados nos braços enlaçados aos ombros e mãos apoiadas nas coxas.

Ainda rompendo um padrão de seriedade, o treinador do time está com uma informal camiseta regata de listras claras e um curto short branco assim como seu calçado. Parece possível intuir, com tais detalhes, o empenho de um time de futebol de subúrbio bem-organizado, e contraditoriamente, a amistosa desordem de arranjos de desejos de um grupo de amigos que mais se aventura e se diverte no esporte do que se coordena pela disciplina de um ethos profissional.

$\mathrm{Na}$ Figura 7, captura digital do álbum de um dos membros do Resenha, apresentam-se os indícios de uma conquista passada. Homens uniformizados de amarelo, azul e verde posam com uma taça prateada. Crianças se escondem por detrás das pernas dos jogadores. Um menino se espreme entre os adultos e abaixo do troféu para aparecer na imagem. Evidências do presente também se apresentam ao lado esquerdo da foto: a textura do tecido branco e a pintura logo acima parecem indicar que ela tenha sido feita por sobre um tipo de pano de prato muito comum no Ceará. Há também marcas de desgaste na borda da capa do álbum e reflexos no plástico que envolve a fotografia.

\section{Figura 7 - Jogadores do Brasileirinho comemoram uma vitória}

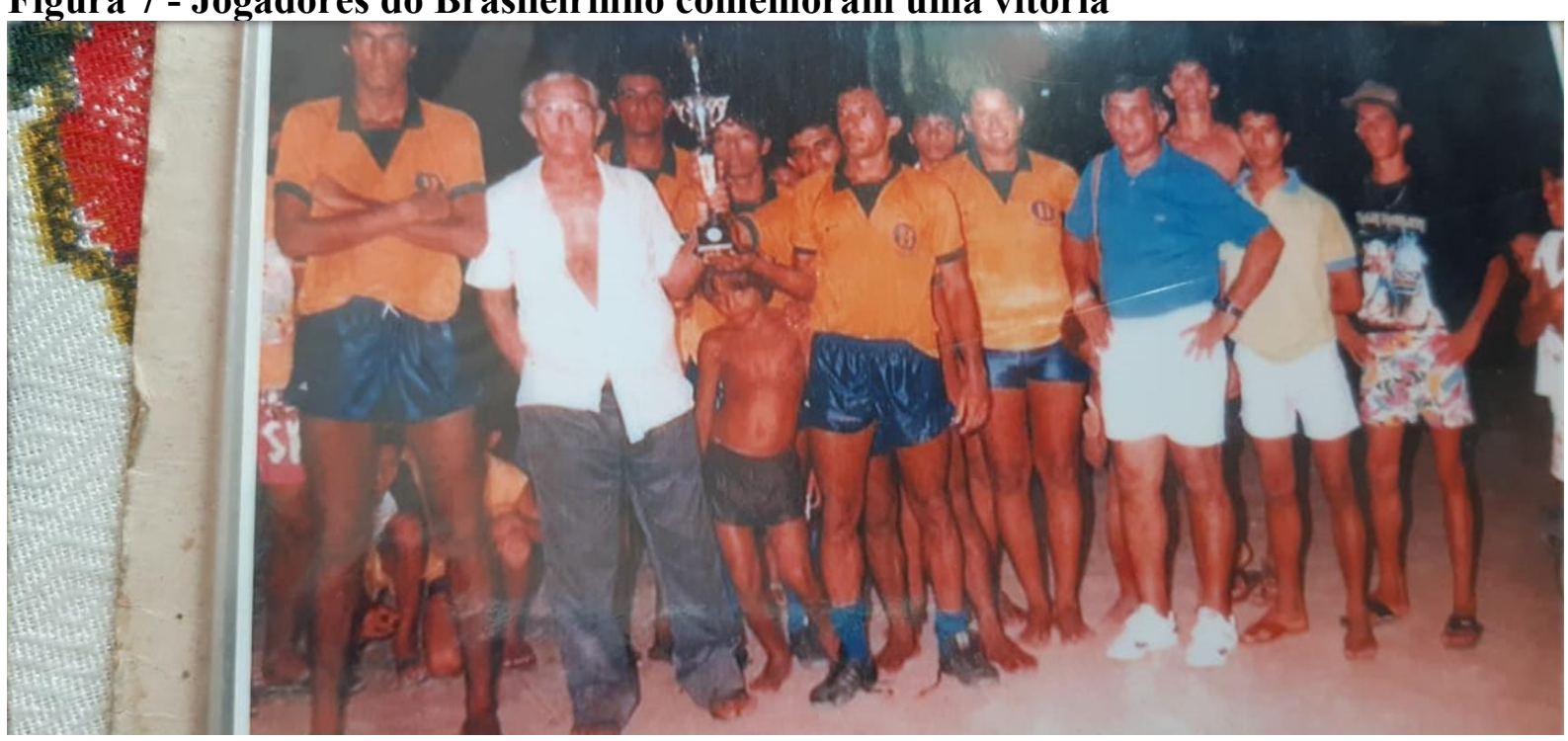

Fonte: grupo de WhatsApp Resenha do Brasileirinho.

É curioso perceber que se listarmos as texturas e marcas nos arredores dessas digitalizações feitas com celular, podemos imaginar fragmentariamente os ambientes das 
casas de seus autores, por onde eles perambulam com suas fotografias. Fotos fixas nas paredes da sala, dos corredores, do banheiro. Fotos nas caixas de sapato. Fotos carregadas para onde houver luz para serem fotografadas com o smartphone. Fotos levadas de debaixo da cama para a superfície da colcha, do quarto para o quintal, da sala para a cozinha, da calçada de casa para a mesa da lanchonete no outro lado da rua. Assim, a imagem que já tornava visível um tanto da história da comunidade e de seus moradores, anos depois de sua feitura, passa a carregar consigo um pouco mais de informação.

\section{Figura 8 - Cópia digital de foto antiga do Brasileirinho Futebol Clube, com descrição de jovens moradores que formaram geração seguinte do time}

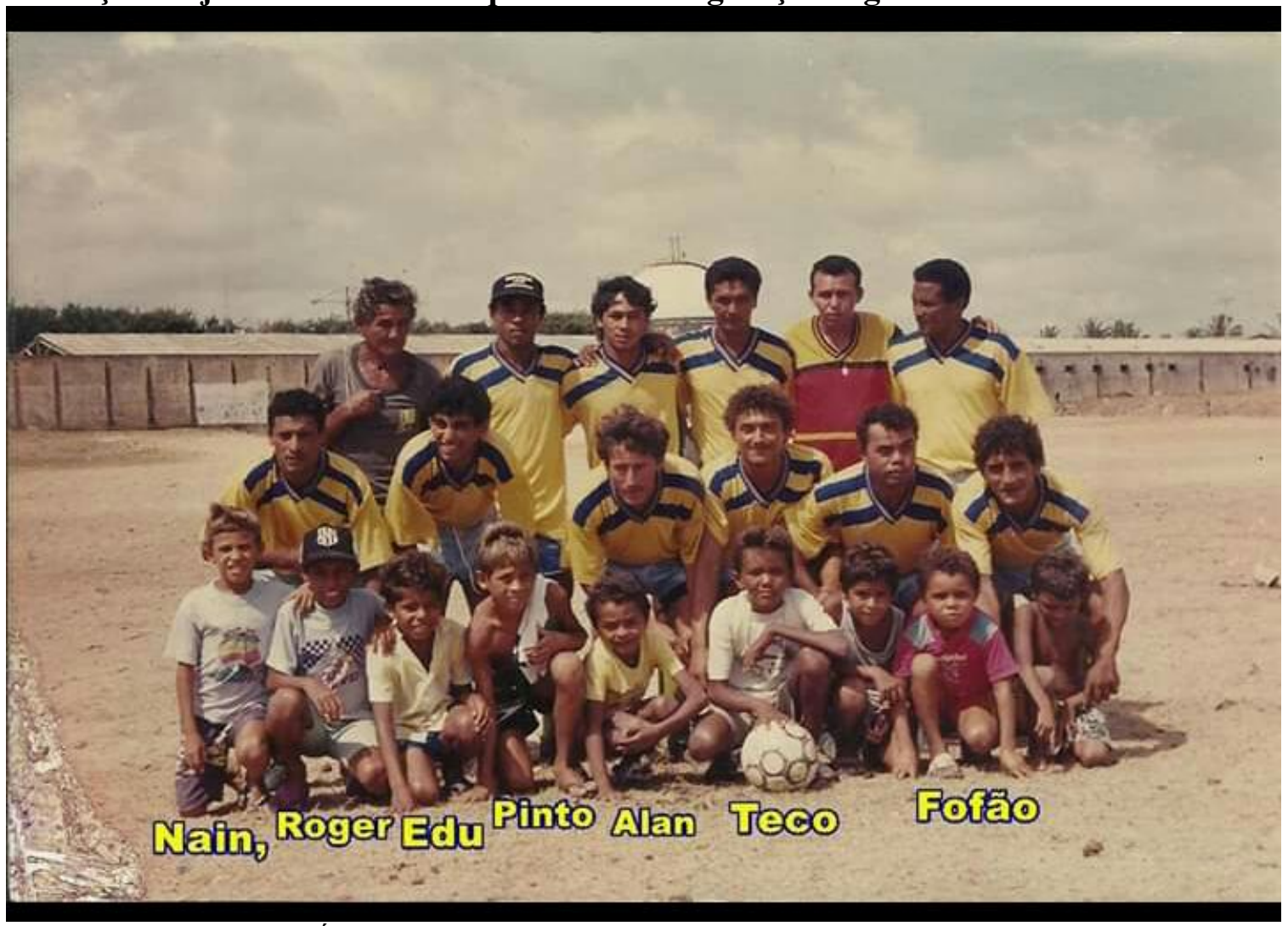

Fonte: Acervo pessoal de Álvaro Graça Jr.

A Figura 8 que Álvaro G. Jr. compartilhou conosco por WhatsApp traz muitos indícios disso. É interessante observar que ela carrega em si marcas de uma longa travessia até chegar diante de nós. Se à esquerda e abaixo há textura de desgaste do papel fotográfico, as barras pretas abaixo e acima e o texto inserido nela indicam que a imagem em questão não é cópia em primeira mão de uma foto impressa, mas uma digitalização interferida antes de ser compartilhada. É possível ainda que se trate de uma "captura de tela" de imagem compartilhada em uma rede digital por outra pessoa. Ou seja, mesmo uma velha imagem feita com câmera analógica nos anos 1990 pode passar por muitas 
transformações em meio digital e ir ganhando novas informações e novos sentidos na medida em que avança de um celular para outro. Essa foto já chega nas mãos de Teco com camadas de texturas entre o analógico e o digital que aludem a diferentes temporalidades na mesma imagem.

Ali figuram em uma clássica pose de time de futebol duas gerações do Brasileirinho: a de Alvinho ali entre os adultos, uniformizado de pé, o terceiro à direita de quem vê; e a de Teco que aparece entre as crianças agachadas. $\mathrm{O}$ texto parece ter sido colocado por alguém que mais se interessava em identificar os jovens que os adultos. Em meio à diversidade de cores de peles de maioria escura, não é amplo o espectro de gênero. Há homens e meninos na foto, evidenciando o que pudemos observar como um meio de vocabulário e práticas marcadamente masculinas. Ao lado de Teco está seu outro irmão Alan e mais à esquerda Edu "Mente-fria" que assim como Álvaro também produziu documentários que compartilha no YouTube com fotografias sobre o Poço e o universo do futebol ali $^{34}$. Duas coisas chamam a atenção para o universo do futebol amador nessa, como em outras, fotos de pose do Brasileirinho. Se nem todos os 23 ali estarem igualmente uniformizados olhando para a câmera no momento do clique for motivo suficiente para o observador intuir um ar informal na equipe, favorecerá tal ideia o fato de estarem num campo de areia com construções ao fundo distintas do que esperaríamos de um estádio de futebol.

É importante salientar que há na figura uma importante mudança de códigos, não apenas porque informa algo mais ao saltar do analógico para o digital, mas porque são diferentes os fotógrafos, as práticas e os contextos da primeira vez em que a foto foi feita para o momento da "foto da foto", quando ela se converte em imagem conectada 35 (Santos, 2016).

No primeiro momento, a foto é feita para registrar um evento; no segundo, para testemunhar a narrativa no WhatsApp de seu novo autor, que não se incomoda que sua cópia carregue informação de panos-de-prato, colchas de cama e paredes de sua casa. A transcodificação tão peculiar de uma imagem como essa para o universo digital nos permite imaginá-la inaugurando mais um momento de seu envelhecimento, carregando as manchas e os desbotados característicos da fotografia impressa, assim como,

\footnotetext{
${ }^{34}$ Disponível em: https://www.youtube.com/watch?v=T91J0t5KG6c. Acesso em: 1 ago. 2019.

${ }^{35}$ A imagem conectada é "um objeto com vocação social cotidiana" (Santos, 2016: 1).
} 
emoldurando a figura desbotada, apresentam-se fragmentos de tecidos e outros objetos registrados com aspectos estéticos de fotografia de celular.

É assim que o resenhista, de celular na mão, no intento de contar uma história, acaba contando duas ao fotografar as imagens em sua parede. Por carregar em si mais histórias do que aquela à qual ele se refere, a imagem narra memórias do time e da casa de seu autor. Ao contar sua história, conta-se a do Poço também. Ao contar a história do Brasileirinho, as fotos dos velhos jogadores contam também a história dos meninos do Poço.

Foi Teco, um desse meninos do Poço dos anos 80, quem lentamente nos apresentava, ao longo de 04 anos, os personagens da história que ele gostaria de contar e a qual ele se refere eventualmente com mais entusiasmo do que quando relata outros pedaços de sua própria biografia. Mais do que "contar a história da minha vida", observamos em Teco um desejo de "lembrar a história da qual eu fiz parte". E, claro, na medida em que nos surpreendiam esses velhos memorialistas de esquina cheios de fotos nos celulares como seu próprio pai Alvinho, Teco viu a oportunidade de reuni-los em um grupo de WhatsApp, o Resenha do Brasileirinho, durante a pandemia de Covid-19 e instigá-los a trabalhar juntos suas memórias e imagens. Assim, Álvaro G. Jr. se encontrava numa interessante posição intermediária entre o universo autobiográfico e etnográfico/documental - e também num entreposto geracional entre as práticas de imagem no Poço da Draga, entre aqueles nas esquinas narrando suas biografias e os jovens documentaristas que se servem das fotografias e histórias desses primeiros para fazer filmes. Muito provavelmente por aquilo que nos lembra Benjamin (1994: 200), “o senso prático é uma das características de muitos narradores natos". É no fluir do território de uma comunidade de laços estreitos que imagens potencializam o lembrar coletivo.

A paixão pelo futebol, década de 80-90, é diferente do que é hoje [...] pelos áudios que a galera fala, porque eu era, menino! Eles falando "porra! A galera tinha a paixão mesmo de sair, de tá jogando, de sair pra jogar, de vestir a camisa de subúrbio, representar. Mesmo sendo de subúrbio". [...]. A gente já tava parando por questão de falta de jogador, né? [...] Aí, quando a gente pensou em voltar, a facção chegou junto. Ainda marcamos alguns jogos, mas por questão de 'ah, tu mora onde?' Queria saber negócio de facção e tudo, aí a gente desistiu (informação verbal) ${ }^{36}$

Hoje, em 2021, o Brasileirinho é lembrado com saudosismo. Por motivos diversos, o time parou suas atividades em 2005, deixando para jogadores mais jovens,

\footnotetext{
${ }^{36}$ Teco, entrevistado em 3 de julho de 2020.
} 
como Álvaro Graça Júnior, a missão de tentar manter o time unido. Os diretores alegam que a parada do time se deu mesmo em 2015, tanto pelo conflito entre facções, que dificultava a movimentação dos times de futebol de subúrbio, quanto pelas dificuldades de compor uma nova geração de jogadores. Isso, porém, não impediu que as resenhas do time continuassem a acontecer nas calçadas do Poço, na Praia e pelo WhatsApp. Esse “desejo consciente de vida" é pujante na fala de Alvinho:

Rapaz, com certeza deus vai nos ajudar e nós vamos continuar com o time. Porque esse time, pra nós, é uma paixão. Ele não morreu. Ele ainda tá aqui. Na hora que abrirem os caminhos lá, nós formamos o veterano. A gente forma um aspirante, um titular. Porque no veterano, quem vão jogar são os velhos, né? Eu só vou jogar até os 80. [risos] A minha doutora 'rapaz, você tem que correr', 'Doutora, acabaram com tudo meu. Não tenho mais praia. Não tenho mais o jogo pra jogar'. Mas aí se voltar...tu é louco, é? Eu volto. A gente volta tranquilo. (informação verbal) ${ }^{37}$

Marcado pelo mar de pelo menos quatro maneiras, Alvinho é nascido em comunidade litorânea; é pescador, portuário e jogador de um time que se fez e treinou na beira de praia. É muito simbólico que ele se refira ao mar para falar de seu esporte, de seu trabalho e de sua saúde, como se ali fosse um ponto de convergência entre seus ofícios e seus lazeres. Trajetória parecida vemos entre alguns outros membros da equipe. $\mathrm{O}$ Brasileirinho é, portanto, essa metonímia de sua própria comunidade: marcado pela história de formação da cidade de Fortaleza, desabrochou em uma cultura praiana, portuária e apaixonada por esporte.

Percebemos também nas falas de Álvaro Jr. e de Alvinho um forte apelo do território, da ancestralidade e da transmissão geracional (e oral) da prática do futebol. Com isso, é interessante observar que é nesse contexto de comunidade e oralidade dos nossos memorialistas de esquina em que se observa sua contumaz prática de imagens, como se as resenhas na barca, que animavam as práticas narrativas em grupo, criasse condições favoráveis para vivências semelhantes com suas fotografias.

\section{Conclusões provisórias sobre a comunidade visível}

Muitas vezes nos impressionaram situações não planejadas como essa: um narrador idoso conta sua história com o celular numa mão e os dedos da outra a tatear imagens no aparelho. Como já observava Benjamim (1994), é também com as mãos que o narrador conta sua história. Ele imprime suas digitais na tela do celular para tracejar um

${ }^{37}$ Alvinho, entrevistado em 17 de julho de 2020. 
percurso em sua constelação de imagens ou para apontar um rosto de quem hoje sente falta. $\mathrm{O}$ que ele conta atravessa gerações de vizinhos e de lugares na comunidade que por prática se faz visível, uma vez mais. Atentos aos seus movimentos, percebemos uma atitude tática (Certeau, 2009) por parte desses memorialistas de esquina, os quais, burlando a falta de um arquivo profuso de imagens, livros e monumentos que registre suas histórias formalmente, articulam um certo agregado de corpos, dispositivos, vozes e imagens em seus trabalhos de memória. Contar uma simples narrativa biográfica pode ser um exercício de atualização coletiva daquilo que conta.

No WhatsApp da "Resenha do Brasileirinho", tanto o jovem Teco como veteranos como seu pai tomam parte nessa mistura de pessoas, lugares e histórias que encontram na prática de imagens conectadas (Santos, 2016) um vetor de produção de sentidos. Corpos pretos contra o esquecimento. Ao observá-los, seguimos as pistas de Diógenes $(2015)^{38}$, conduzindo os esforços etnográficos entre ambiências on-line e off-line conforme se apresentavam as práticas de nossos narradores e a intensidade de suas interações face a face ou digitalmente. Se o encontro presencial permitia ver o manuseio de suas fotos, era no WhatsApp que debatiam, riam e brigavam diante das imagens. Não se tratam, porém, de polos distintos de observação. É no entre, nas intercessões que nos concentramos quando, por exemplo, um velho jogador compartilha no grupo um vídeo seu caminhando pela região para mostrar como está o lugar para um outro que não vive mais ali. É assim também que a experiência coletiva digital potencializa o habitar e o lembrar. Possibilita suscitar o aparecimento, ou o encontro de imagens (Didi-Huberman, 2103: 18), de relações entre elas, de correspondências possíveis, capaz de assim se fazer surgir, entre e a partir dos memorialistas da esquina, um conhecimento inesgotável de uma história ainda não contada que vai sendo continuamente mostrada.

Nos detivemos, neste artigo, naqueles que praticam as imagens que lhes são caras, que lhes afetam porque falam de si e dos seus - e que nesse sentido podem chamá-las de suas, imagens que, por vezes, sequer foram feitas por quem as possui. "Nesse deserto lúgubre, me surge, de repente, tal foto; ela me anima e eu a animo [...] é o que toda aventura produz" (Barthes, 2015: 25). São inúmeros e arbitrários os traços através dos quais nos aventuramos diante de nossas "velhas fotografias". É na prática dessas imagens que o narrador anima sua narrativa.

\footnotetext{
${ }^{38}$ Glória Diógenes (2015) implementa "um itinerário marcado por intervenções de artistas urbanos que se moviam entre uma zona de Lisboa e ambiências das redes sociais digitais". Disponível em: http://etnografi ca.revues.org/4105. Acesso em: 21 maio 2019.
} 
Em alusão a um Atlântico negro, caracterizado pela diáspora africana, Paul Gilroy menciona a diversidade e a vitalidade da música negra cubana, jamaicana e brasileira do século XX pontuando que "a alienação natal e o estranhamento cultural são capazes de conferir criatividade e de gerar prazer" (Gilroy, 2012: 20). Com isso nos conta que os povos dispersados, para além da dor, experienciaram os efeitos de seus deslocamentos de formas criativas, mais centrados nas misturas que em restituir uma centralidade de origem étnica. A diaspórica e multicolorida paisagem étnica da comunidade centenária do primeiro porto de Fortaleza, marcada pela memória do colonialismo e das fugas populacionais das grandes secas, e mesmo pelas tradições litorâneas indígenas, menos preocupada com sua afirmação étnica originária, encontra em suas misturas as estratégias de conservação da memória de seu território por meio de álbuns, fotos, celulares, filmes e não só. Não deixemos de responsabilidade do acaso que no Poço da Draga haja em suas calçadas tal prática oral de narradores que tão espontaneamente sacam fotos em seus celulares que remontam décadas da história de seu lugar. Há, sim, um devir negro, uma persistência da memória em ser recontada boca a boca, geração a geração. Há um devir negro em suas prazerosas práticas de imagem.

Em território de lembrança e herança colonial, de resistência negra em nossa Fortaleza, os trabalhos da memória dos descendentes do Poço não devem ser encarados apenas como passatempo ou curiosa obsessão de idosas e idosos. O que os memorialistas de esquina acumulam para sua coletividade é algo como um capital, baseado em lembrar e ser lembrado por gerações. O que nos contam, e como transmitem de uma geração para a outra, está longe de mero deleite pueril ou de se enquadrar como padecimentos de memórias ressentidas que não deixam o passado passar. Admitimos que haja, é claro, como força propulsora do desejo de lembrar e ser lembrado, a lembrança do apagamento colonial, como nos lembra Grada Kilomba (2019), "memorizado" no sentido em que "não foi esquecido". No entanto, há algo de afirmativo, de devir, de uma política da alegria em sua partilha do sensivel (Rancière, 2009) com a qual os memorialistas de esquina compartilham, reavivam, remontam e remontam suas histórias diante de fotografias partilhadas pelo WhatsApp.

Por fim, destacamos essa significativa prática colaborada de pensar imagens de um lugar com aqueles que as cuidam, praticam e partilham. Impressiona que em território desprestigiado pelo poder público, marcado pela necropolítica (Mbembe, 2018), pela incerta permanência dos moradores, as fotografias ali carreguem a resistência e a 
fascinação daqueles que as animam e se animam com elas: os memorialistas de esquina da comunidade visivel.

\section{REFERÊNCIAS}

AGAMBEN, Giorgio. O que é um dispositivo? Outra travessia, Florianópolis, n. 5, 2005.

Disponível em: https://periodicos.ufsc.br/index.php/Outra/article/view/12576/11743. Acesso em: 14 ago. 2016.

AGAMBEN, Giorgio. O que é o contemporâneo? E outros ensaios. Chapecó, SC: Argos, 2009.

AZEVEDO, Nirez. História do Campeonato Cearense de Futebol. Fortaleza: Equatorial Produções, 2002.

BARTHES, Roland. A Câmara Clara. Rio de Janeiro: Nova Fronteira, 2015.

BAUMAN, Zygmunt. Comunidade: a busca por segurança no mundo atual. Rio de Janeiro: Jorge Zahar, 2003.

BENJAMIN, Walter. O Narrador: considerações sobre a obra de Nikolai Leskov. In: Magia e técnica, arte e política: ensaios sobre literatura e história da cultura. São Paulo: Brasiliense, 1994. p. 197-221.

BOSI, Ecléa. Memória e Sociedade: Lembrança de Velhos. 2. ed., São Paulo: T.A. Queiroz, 1994.

BRUNO, Fabiana. Fotobiografia: por uma metodologia da estética em antropologia. RESGATE, v. 18, n. 19, p. 27-45 jan./jul. 2010 Disponível em: https://doi.org/ 10.20396/resgate.v18i19.8645677. Acesso em: 20 maio 2019. 
BRUNO, Fabiana. Uma antropologia das "supervivências": as fotobiografias. In: SAMAIN, Etienne. (Org.). Como pensam as imagens. Campinas, SP: Editora da Unicamp, 2012. p. 91-106.

CASTELLS, Manuel. O poder da identidade. A era da informação: economia, sociedade e cultura. São Paulo: Paz e Terra, 1999. v. 2.

CERTEAU, Michel de. A invenção do cotidiano: 1. as artes de fazer; $16^{\mathrm{a}}$ Ed. Tradução de Ephraim Ferreira Alves. Petrópolis, RJ: Vozes, 2009.

DIDI-HUBERMAN, George. O que vemos, o que nos olha. São Paulo: Editora 34, 1998.

DIDI-HUBERMAN, George. Atlas ou a gaio saber inquieto - O olho da história, III. Belo Horizonte: UFMG, 2018.

DIDI-HUBERMAN, George. Atlas ou a Gaia Ciência Inquieta. Lisboa: Imago, 2013.

DIÓGENES, Glória Maria dos Santos. A arte urbana entre ambientes: dobras entre a cidade material e o ciberespaço. Etnográfica, v. 19, p. 537-556, 2015.

FLUSSER, Vilém. Filosofia da Caixa Preta: ensaios para uma futura filosofia da fotografia. Rio de Janeiro: Relume Dumará, 2012.

FOUCAULT, Michel. Sobre a História da sexualidade. In: . Microfísica do poder. Rio de Janeiro: Graal, 2000. p. 243-27.

FOUCAULT, Michel. História da sexualidade I: A vontade de saber. São Paulo: Graal, 2009.

GALEANO, Eduardo. Futebol ao sol e à sombra. Porto Alegre: L\&PM, 2019.

GILROY, Paul. O atlântico negro: modernidade e dupla consciência. São Paulo: Ed.34, 2012 . 
GONDIM, Linda Maria de Pontes. A construção social da memória na moderna Fortaleza. In: AGUIAR, Odílio et al. (Org.). Olhares contemporâneos: cenas do mundo em discussão na universidade. Fortaleza: Edições Demócrito Rocha, 2001.

INGOLD, Tim. Editorial. Man, v. 27, n. 1, p. 694-697, 1992.

INGOLD, Tim. Trazendo as coisas de volta à vida: emaranhados criativos num mundo de materiais. Revista Horizontes Antropológicos, Porto Alegre, v.18, n.37, jan./jun. 2012.

KARDOZO, Felipe Camilo Mesquita. Confissões no Facebook: educação e subjetivação nas redes sociais. 2013. Dissertação (Mestrado) - Universidade Federal do Ceará, Faculdade de Educação, Programa de Pós-Graduação em Educação Brasileira, Fortaleza, 2013.

KARDOZO, Felipe Camilo Mesquita. Comunidade Visivel: narradores de imagens e memórias do Poço da Draga. 2021. 325 f. Tese (Doutorado em Sociologia) - Programa de Pós-graduação em Sociologia, Centro de Humanidades, Universidade Federal do Ceará, $\quad 2021$ Fortaleza, Disponível em: https://www.repositorio.ufc.br/handle/riufc/58602 .

KILOMBA, Grada. Memórias da plantação: episódios de racismo cotidiano. Rio de Janeiro: Editora Cobogó, 2019.

LATOUR, Bruno. Jamais fomos modernos, Crise. São Paulo: Editora 34, 1994. 152p.

MBEMBE, Achille. Crítica da Razão Negra. Lisboa: Antígona, 2014.

MBEMBE, Achille. São Paulo: N-1 edições, 2018.

PASSOS, Marília A. G. Um mar de histórias: memória, identidade e territorialidade no Poço da Draga. 2019. 281 f. Tese (Doutorado) - Universidade Federal do Ceará, Centro de Humanidades, Programa de Pós-graduação em Sociologia, Fortaleza, 2019. 
PONTES, S. R. B. Fortaleza Belle Époque: reforma urbana e controle social 1860 - 1930. 5. ed. Fortaleza: Edições Demócrito Rocha, 2014. 224p.

RANCIÈRE, Jacques. O inconsciente estético. Rio de Janeiro: 34 Editora, 2009.

ROCHA, Francisco Sérgio et al. Conhecendo o Poço Da Draga: Uma Proposta Conjunta de Levantamento de Informações sobre a Comunidade. URBS Favela - II Seminário Brasileiro de Urbanização de Favelas. Anais... 2016. Disponível em: http://www.sisgeenco.com.br/sistema/urbfavelas/anais2016/ARQUIVOS/GT4-226-15120161013155510.pdf. Acesso em: 20 mai. 2019.

RODRIGUES, N. S. Organizações não governamentais: o caso da Velaumar/ Assessoria, desenvolvimento e cidadania (Fortaleza-CE). Acta Académica do XXXI Congreso ALAS 2017. Montevidéu: ALAS, 2018.

SAMAIN, E. (Org.). Como pensam as imagens. Campinas: Editora da Unicamp, 2012.

SANTOS, Francisco Coelho dos. As faces da selfie: Revelações da fotografia social. Rev. bras. Ci. Soc. [on-line], v. 31, n. 92, 2016. Disponível em: http://dx.doi.org/10.17 666/319202/2016. Acesso em: 24 jul. 2019.

SIBILIA, Paula. O show do eu: subjetividade nos gêneros confessionais da Internet. Rio de Janeiro: UFRJ, 2007. Tese (Doutorado em Comunicação e Cultura) Programa de Pós-Graduação da Escola de Comunicação da Universidade Federal do Rio de Janeiro, Rio de Janeiro, 2007.

VIVEIROS DE CASTRO, Eduardo. O Nativo Relativo. Mana, Rio de Janeiro, v.8, n.1, 2002. Disponível em http://dx.doi.org/10.1590/S0104-93132002000100005. Acesso em: 24 jul. 2019.

WARBURG, Aby. Atlas Mnemosyne. Madri: Akal, 2010. 
WHYTE, William Foote. Sociedade de esquina. Rio de Janeiro: Jorge Zahar, 2005.

Recebido: 28/10/2020

Aprovado: 02/06/2021 